\title{
THE USE OF COMPREHENSIVE GERIATRIC ASSESSMENT: A TOOL FOR DONOR SELECTION
}

\author{
Morgani Rodrigues ', Fernando Barroso Duarte², Nelson Hamerschlak'.
}

1.Hospital Israelita Albert Einstein - 2.Hospital Universitário Walter Cantídio

Allogeneic hematopoietic stem cell transplantation (allo- HSCT) is an effective therapy for a variety of malignant and nonmalignant diseases. It provides a life-prolonging or potentially curative treatment option for these patients when clinically indicated.

Several factors interfere with the risk for transplantation-related mortality (TRM), including patient age, donor type, and conditioning regimen intensity. Given the high transplant-related morbidity, these treatment strategies were initially restricted to younger patients, but are increasingly used in older adults [1-3]. The advent of reduced intensity and nonmyeloablative preparative regimens, coupled with substantial improvements in supportive care, have resulted in increasing numbers of older adults referred for allogeneic transplant [4,3,5]; indeed, approximately $40 \%$ of transplant recipients in the last decades were over 50 years [3]. Yet, the overall survival (OS) in older patients have not yet been fully elucidated regarding who will have the best benefit for such therapy, since not all older patients are referred to transplant evaluation.

In Brazil until the last year, only young patients were allowed to received allogeneic HSCT in the public health system (SUS - Sistema Único de Saude). The new regulation (PORTARIA número 1813 de 22 de Julho de 2020) of HSCT in Brazil make it possible. Now patients aged 75 years old or younger get a HSCT. For instance the choice of patients who will best have benefit with transplant is necessary.

The standard pre-transplant evaluation provides a detailed assessment of the many health-related factors that predict clinical outcomes; however, older adults are predisposed to a unique set of medical and social characteristics that may not be prevalent in young individuals, but may impact outcomes in elderly patients. Changes in cognitive function, hearing problems, falls, urinary incontinence are rare in young transplant patients, but much more frequent in older adults. The age alone is not the best predictor of HSCTrelated toxicity, while the comorbidities and functional status of the older patients are likely better predictors of toxicity than the chronologic age

The use of comprehensive geriatric assessment (CGA) in older adults who are candidates to hematopoietic stem cell transplantation HSCT) may improve the detection of potential risks in pre-transplant assessment in addition to the traditionally used comorbidity scores, such as Hematopoietic stem cell comorbidity index $(\mathrm{HCT}-\mathrm{Cl})$, enabling the detection of vulnerabilities commonly found in this population.

The CGA can also, when recognizing vulnerabilities, intervene for patient's clinical improvement before, during and after transplant.

The standard domains commonly assessed by the CGA are: functionality, mental health, cognition, nutrition, polypharmacy, comorbidities and social support (Table 1).

\section{CGA AND HSCT}

Muffly et al. (6) reported a high prevalence of vulnerabilities through CGA among older adults' recipients of allo- HSCT. They showed that deficiencies were present in $40 \%$ according to the assessment of the IADL (Instrumental activities of daily living). Self-reported physical and mental functions were significantly worse than expected for each related age group; $58 \%$ were considered pre-frail and $25 \%$ frail. Lin et al also found changes in ADL (activities of daily living) and IADL (Instrumental activities of daily living) in almost half of the patients, of which $81 \%$ had more than one ADL / IADL impairment and deficit and one third had cognitive changes [8].

Cognition impairments were found in 5 to $47 \%$ of patients and can be seen as early as 6 months after myeloablative allo- HSCT and up to 3 years in reduced intensity regimes. In autologous HCT 19-26\% 
of adults (age $\geq 18$ ) had cognitive impairment compared with $9-20 \%$ of healthy controls. The recovery and persistence of neurocognitive dysfunction is highly variable after transplantation and can impact the quality of life of these patients [7]

The presence of Nutritional Risk is another important domain. It was found in $36 \%$ to $76 \%$ of transplanted patients [9]. Around $58 \%$ aged $\geq 50$ have significant weight loss; $15 \%$ of patients with hypoalbuminemia. [10] It is important to identify the nutritional risk early, as they can benefit from referral to a nutritionist before HCT being in a better condition for transplantation

Physical functionality has been the most well-established domain of CGA as a predictor of survival and treatment toxicities in allo- HSCT. In a multicenter study without restricting the age of adult patients who were candidates for HSCT, the presence of better physical functionality was related to better survival and unrelated mortality [11]. Recently Olin et al [12] showed that in older allo- HSCT recipients, cognitive impairment is associated with worse survival (HR 1.94; $P=.01)$ and increased mortality (HR: 2.36; $P=.01$ ); being a new risk factor to be considered in older adults candidates for HCT.

One of the first studies in prognostication was carried out by Muffly et al [10] who prospectively evaluated, in a single institution, the prognostic role of CGA in 203 patients who received an allogeneic transplant, The patients were aged 50-73 years (average of 58 years). In the multivariate analysis, some factors associated with worsening overall survival were identified: the IADL score, the slow gait speed, high HCT$\mathrm{Cl}$ scores and impaired mental health, evaluated by SF-36 (Short Form) questionnaire. [36], The limitations in IADL were the greatest predictor for worsening of overal survival (OS) (HR of 2.28; $p<0.001$ ). The impact was even greater in patients over 60 years of age (HR 3.25; $p<0.001)$. In this study, IADL with HCT$\mathrm{Cl}$ were also combined in a single 3-point model: an $\mathrm{HCT}-\mathrm{Cl}$ score greater than or equal to 3 or IADL with a score $<14$ would lead to a combined score of 1 . Both abnormalities would point a score of 2. Patients with a score of 0 (without scoring HCT-Cl and IADL score) have a OS of $62 \%$, and those with a score of 1 (one of the two scores) and 2 (the two scores) have a OS of 44 and $13 \%$ respectively. None of the patients aged 60 years or over with the combined score of 2 survived more than 2 years.

More recently, Polverelli et al [13] evaluated the feasibility and efficacy of a multidimensional geriatric evaluation, used by the Fondazione Italiana Linfomi
(FIL), in a cohort of 228 patients over 60 years old who underwent allo- HSCT in Italy and France from 2008 to 2018 . A total of 228 patients were evaluated. The score consisted of 4 domains: 1- CIRS-G, (geriatric specific comorbidity score); 2- ADL; 3-IADL and 4- age over 80 years. The patients were then classified as robust, frail and vulnerable. The FIL score was considered a predictor of survival: patients in the vulnerable and frail group had excess mortality unrelated to relapse.

The importance of CGA in the bone marrow transplant scenario is being increasingly analyzed and recent studies reinforce its importance in the prognosis and intervention to improve the health condition of patients before the transplant and even in the post-transplant period $(8,10,14-18)$. The CGA tools studied in bone marrow transplantation are summarized in Table 1.

\section{SCREENING TOOLS X CGA}

The CGA is considered a very complete tool but it takes some time to complete it and requires a geriatrician to analyzed it. For this reason Homes et al tried to evaluate other two screening tools compared to CGA: The Elderly Vulnerability Survey (VES13) and the G8 screening tool, for abnormal CGA or frailty criteria. It was analyzed Fifty patients who were candidates for allo-HST aged 60 years or older were included. The CGA variables included: medical history, physical, functionality and social health. Frailty was defined as three or more abnormalities in the criterion of physical strength, gait speed, weight loss, tiredness and activity level. Thirty-three patients (66\%) with a mean age of 65.4 years had abnormal CGA and 11 patients (22\%) were considered frail. The G8 screening tool showed greater sensitivity in detecting abnormality in the CGA (69.7\%), and VES13 had a higher specificity (100\%). Both tools had a similar discriminatory capacity. The authors concluded that elderly patients who are candidates for HCT had a significant number of deficits in the CGA domains, and a high prevalence of frailty and the existing screening tools cannot be able to replace the complete performance of CGA.

A new scale developed especially for hematological patients by the Spanish group, the GHA (Geriatric Hematologic assessment) [20] has managed to discern groups of toxicity and is also sensitive to clinical changes in the patients' health status [21]. GHA has 30 items divided into 8 categories that include CGA to categorize patients into healthy, or vulnerable to standard treatments based on clinical, functionality and mental status. It takes about 11 minutes to do and does not 
need to be applied by a doctor. Unfortunately, we don't have still data in the use of HSCT scenario.

In October 2020 during de the Annual Brazilian Society of Bone Marrow transplant congress (SBTMO) a consensus meeting rouse this discussion on the agenda since the increased number of older adults transplanted coupled with the new regulation ( Portaria No 1813) is a reality.

The application of CGA before HSCT has become practically mandatory for patients over 60 years old, some European groups have already applied it over 50 or 55 years old. We believe that the most important is the individualization of treatment, and that in fact the age group is not the only criterion in the eligibility for HSCT nor in the choice of the type of conditioning. For this reason, we have added this new chapter to the 2020 consensus of SBTMO in an unprecedented way. The committee also propose a development a study group in the field of HSCT in older adults with the aim in improving outcomes and quality of life of these patients.
Due the lack of robust data in witch are the best CGA tools and how to better select patients for transplants; our suggestion, based on our experience and literature [10],[19], is to use the routine recommended for the evaluation of older adults with cancer (as suggested in table 1 ) At a minimum, the tools should cover physical functionality to complement the comorbidity scores: For example: the use of IADL together with HCT-Cl has already been shown to be a predictor of overall survival [10]. The use of screening tools is open for validations in the HSCT. Some trials are underway as the BMT CTN Protoco I1704 CHARM and can, in the future, bring more information.

Patients with no Will in get a transplant; Cognitive disability, Falls and postural instability, Immobility, Family / social support failure and high HCT-Cl score are non-candidates for HSCT and alternatives treatment should be offered.

Members of committee: Dra Morgani Rodrigues, Dr Nelson Hamesrclak, Dra Polianna Mara Rodrigues de Souza, Dra Natália Costa and Dr Fernando Barroso.

TABLE 1 - CGA Domains and CGA domains in HCT. Adaptad from R. Jayani, et al. (19)

\begin{tabular}{|c|c|c|}
\hline CGA Domains & CGA - Tools in HCT & Others impairments/tools \\
\hline $\begin{array}{c}\text { Comorbidity } \\
\text { Number } \\
\text { Type } \\
\text { Gravidity } \\
\text { Risk of worsening during Cancer } \\
\text { treatment }\end{array}$ & $\begin{array}{l}\mathrm{HCT}-\mathrm{Cl} \text { (Hematopoietic stem cell } \\
\text { transplant comorbidity index.) }\end{array}$ & $\begin{array}{l}\text { Urinary, vision, hearing impairments; } \\
\text { Diastolic dysfunction; Osteoporosis; } \\
\text { Previous renal impairment }\end{array}$ \\
\hline $\begin{array}{l}\text { Physical Function } \\
\text { ADL } \\
\text { IADL } \\
\text { Status performance } \\
\text { Falls } \\
\text { Gait speed }\end{array}$ & $\begin{array}{l}\text { IADL } \\
\text { Timed up and Go test } \\
\text { Gait speed } \\
\text { Number of falls } \\
\text { Grip strength }\end{array}$ & $\begin{array}{l}\text { Arthritis } \\
\text { Exercises } \\
\text { balance }\end{array}$ \\
\hline $\begin{array}{l}\text { Cognition } \\
\text {-decision-making ability } \\
\text { - Dementia } \\
\text { - Depression } \\
\text { - delirium } \\
\end{array}$ & $\begin{array}{c}\text { Mini-mental test } \\
\text { MOOCA } \\
\text { Orientation- memory- concentration } \\
\text { tests }\end{array}$ & $\begin{array}{l}\text { Previous History of mental confusion } \\
\text { Loss of memory and duration } \\
\text { Information retation }\end{array}$ \\
\hline $\begin{array}{l}\text { Psychologic } \\
\text { Depression } \\
\text { Anxiety } \\
\text { Distress }\end{array}$ & $\begin{array}{l}\text { GDS (Geriatric Depression Scale) } \\
\text { Mental healthy inventory }\end{array}$ & $\begin{array}{c}\text { Sleep disorders } \\
\text { Motivationto get a Transplant } \\
\text { Resources for dealing with adversity } \\
\text { Expectations in life }\end{array}$ \\
\hline $\begin{array}{l}\text { Social Support } \\
\text { Emotional support } \\
\text { Financial support } \\
\text { Assistance for ADL }\end{array}$ & $\begin{array}{l}\text { MOS (medical outcomes survey) } \\
\text { Social support survey (ISSS) }\end{array}$ & $\begin{array}{c}\text { Presence of caregiver } \\
\text { Use of alcohol } \\
\text { Presence of stairs at home } \\
\text { Person preparing food at home }\end{array}$ \\
\hline $\begin{array}{l}\text { Nutritional status } \\
\text { Unintentional loss of weight } \\
\text { Low BMI } \\
\text { Access to food }\end{array}$ & $\begin{array}{l}\text { Loss of weigth } \\
\text { BMI } \\
\text { Albumin }\end{array}$ & $\begin{array}{c}\text { Last dentist evaluation } \\
\text { Use of dentures } \\
\text { Food supplements } \\
\text { Effects of previous therapies on nutrition and } \\
\text { weight gain }\end{array}$ \\
\hline Polipharmacy & More than 5 medication & $\begin{array}{l}\text { over the counter medication } \\
\text { Previously side effects }\end{array}$ \\
\hline
\end{tabular}




\section{REFERENCES}

1.Hahn T, McCarthy Jr PL, Hassebroek A, Bredeson C, Gajewski JL, Hale GA, et al. Significant improvement in survival after allogeneic hematopoietic cell transplantation during a period of significantly increased use, older recipient age, and use of unrelated donors. J Clin Oncol; p. 2437-2439, 2013.

2.Horan JT, Logan BR, Agovi-Johnson MA, Lazarus $\mathrm{HM}$, Bacigalupo AA, Ballen KK, et al. Reducing the risk for transplantation-related mortality after allogeneic hematopoietic cell transplantation: how much progress has been made? J Clin Oncol; v.29, n.7, p. 805-813, 2011.

3.Center for International Blood \& Marrow Transplantation Research. Summary slides - HCT trends and survival data [internet]. [cited 2017 Apr 2]. Available from: https:// www.cibmtr.org/ referencecenter/slidesreports/summaryslides/ Pages/index.aspx

4.[3] Sorror ML, Sandmaier BM, Storer BE, Franke GN, Laport GG, Chauncey TR, et al. Longterm outcomes among older patients following nonmyeloablative conditioning and allogeneic hematopoietic cell transplantation for advanced hematologic malignancies. JAMA v. 306, n.17, p. 1874-1883, 2011.

5.[7] Devine SM, Owzar K, Blum W, Mulkey F, Stone RM, Hsu JW, et al. Phase II study of allogeneic transplantation for older patients with acute myeloid leukemia in first complete remission using a reduced-intensity conditioning regimen: results from cancer and leukemia group $B$ 100103 (Alliance for clinical trials in oncology)/ blood and marrow transplant clincial trial network 0502. J Clin Oncol; it. v. 33, n. 35, p. 41674175, 2015.

6.Muffly LS, Boulukos M, Swanson K, Kocherginsky M, Cerro PD, Schroeder L, et al. Pilot study of comprehensive geriatric assessment (CGA) in allogeneic transplant: CGA captures a high prevalence of vulnerabilities in older transplant recipients. Biol Blood Marrow Transplant; v. 19, n.3, p. 429-434, 2013.

7.David Buchbinder et al. Neurocognitive Dysfunction in Hematopoietic Cell Transplant Recipients: Expert Review from the Late Effects and Quality of Life Working Committee of the CIBMTR and Complications and Quality of Life Working Party of the EBMT. Bone Marrow Transplant;. v.53, p.535-555, 2018.
8.Lin RJ, Shahrokni A, Dahi PB, Jakubowski AA, Devlin SM, Maloy MA, Robinson KS, Perales MA4, Shah GL4, Korc-Grodzicki B, Giralt SA. Pretransplant comprehensive geriatric assessment in hematopoietic cell transplantation: a single center experience. Bone Marrow Transplantation; v.53, p. 1184-1187. 2008.

9.Muffly L, Pasquini MC, Martens M, Brazauskas R, Zhu X, Adekola K, et al. Increasing use of allogeneic hematopoietic cell transplantation in patients aged 70 years and older in the United States. Blood; v. 130, n.9, p. 1156-1164, 2017.

10.Muffly LS, Kocherginsky M, Stock W, Chu Q, Bishop MR, Godley LA, et al. Geriatric assessment to predict survival in older allogeneic hematopoietic cell transplantation recipients. Haematologica; v. 99, n. 8, p.2014.

11.Wood WA, Le-Rademacher J, Syrjala KL, Jim $\mathrm{H}$, Jacobsen PB, Knight JM, et al. Patient-reported physical functioning predicts the success of hematopoietic cell transplantation (BMT CTN 0902). Cancer; v.122, p.91-98, 2016.

12.Rebecca L. Olin et al. Geriatric assessment in older alloHCT recipients: association of functional and cognitive impairment with outcomes. Blood Advances. 23 JUNE 2020 x VOLUME 4, NUMBER 12.

13.Nicola Polverelli et al. Multidimensional geriatric assessment for elderly hematological patients ( $\geq 60$ years) submitted to allogeneic stem cell transplantation. A French-Italian 10-year experience on 228 patients. Bone Marrow Transplantation; v. 55, p.2224-2233, 2020. https://doi. org/10.1038/s41409-020-0934-1

14. Holmes HM, Des Bordes JK, Kebriaei P, el al. Optimal screening for geriatric assessment in older allogeneic hemaotpoietic cell transplantation candidates. J Geriatric Oncol 2014; 5(4): 422-430

15.Deschler B, lhorst G, Schnitzler S, Bertz H, Finke J. Geriatric assessment and quality of life in older patients considered for allogeneic hematopoietic cell transplantation: a prospective risk factor and serial assessment analysis. Bone Marrow Transplant; v. 53, p. 2018.

16.Nawas MT, Andreais C, Martin TG, Wolf JL, Ai WZ, Kaplan LD, et al. Limitation in patient-reported function is associated with inferior survival in older adutls undergoing autologous hemato- 
poietic cell transplantation. Biol Blood Marrow Transplant. v.25, n.6, p. 1218- 1224, 2019.

17. Huang LW, Sheng Y, Andreadis C, Logan AC, Mannis GN, Smith CC, et al. Functional status as measured by geriatric assessment predicts inferior survival in older allogeneic hematopoietic cell transplant recipients. Biol Blood Marrow Transplant 2019. https://doi.org/10.1016/j. bbmt.2019.08.022 [Epub ahead of print; Pubmed ID: 31493541]

18. Rodrigues M, Rodrigues de Souza PM, de Oliveria Muniz Koch L, Hamerschlak N. The use of comprehensive geriatric assessment in older patients before allologeneic hematopoietic stem cell transplantation: a cross-sectional study. J
Geriatr Oncol 2019. https://doi.org/10.1016/j. jgo.2019.05.022 [Epub ahead of print; Pubmed ID: 31230926].

19.R. Jayani, A. Rosko, R. Olin et al. Use fo Geriatric assessment in hematopoietic cell transplant. $J$ Geriatric Oncol. 2019.

20.Bonand S. et al. Development and psychometric validation of a brief comprehensive health status assessment scale in older patients with hematological malignancies: the GAH scale. J Geriatr Oncol. v. 6, n.5, p. 353-361, 2015.

21.Cruz-Jentoft et al. Further psychometric validation of GAH scale: responsiveness and effect size. J Geriatr Oncol; it. v. 8, p.211-215, 2017. 